\title{
The University of Chicago
}

\section{Self-Serving Assessments of Fairness and Pretrial Bargaining}

Author(s): George Loewenstein, Samuel Issacharoff, Colin Camerer, Linda Babcock

Source: The Journal of Legal Studies, Vol. 22, No. 1 (Jan., 1993), pp. 135-159

Published by: The University of Chicago Press

Stable URL: http://www.jstor.org/stable/3085636

Accessed: $1 1 \longdiv { / 0 2 / 2 0 1 1 1 3 : 2 5 }$

Your use of the JSTOR archive indicates your acceptance of JSTOR's Terms and Conditions of Use, available at http://www.jstor.org/page/info/about/policies/terms.jsp. JSTOR's Terms and Conditions of Use provides, in part, that unless you have obtained prior permission, you may not download an entire issue of a journal or multiple copies of articles, and you may use content in the JSTOR archive only for your personal, non-commercial use.

Please contact the publisher regarding any further use of this work. Publisher contact information may be obtained at http://www.jstor.org/action/showPublisher?publisherCode=ucpress.

Each copy of any part of a JSTOR transmission must contain the same copyright notice that appears on the screen or printed page of such transmission.

JSTOR is a not-for-profit service that helps scholars, researchers, and students discover, use, and build upon a wide range of content in a trusted digital archive. We use information technology and tools to increase productivity and facilitate new forms of scholarship. For more information about JSTOR, please contact support@jstor.org. 


\title{
SELF-SERVING ASSESSMENTS OF FAIRNESS AND PRETRIAL BARGAINING
}

\author{
GEORGE LOEWENSTEIN, SAMUEL ISSACHAROFF, \\ COLIN CAMERER, and LINDA BABCOCK*
}

In life it is hard enough to see another person's view of things; in a law suit it is impossible. [JANET Malcom, The Journalist and the Murderer, 1990]

\section{INTRODUCTION}

\begin{abstract}
A
PERSISTENTLY troubling question in the legal-economic literature is why cases proceed to trial. Litigation is a negative-sum proposition for the litigants - the longer the process continues, the lower their aggregate wealth. Although civil litigation is resolved by settlement in an estimated 95 percent of all disputes, what accounts for the failure of the remaining 5 percent to settle prior to trial?

The standard economic model of legal disputes posits that settlement occurs when there exists a postively valued settlement zone-a range of transfer amounts from defendant to plaintiff that leave both parties better off than they would be if they went to trial. The location of the settlement zone depends on three factors: the parties' probability distributions of award amounts, the litigation costs they face, and their risk preferences.
\end{abstract}

Loewenstein is Professor of Economics, Carnegie Mellon University; Issacharoff is Assistant Professor of Law, University of Texas at Austin School of Law; Camerer is Professor of Organizational Behavior and Strategy, University of Chicago Graduate School of Business; Babcock is Assistant Professor of Economics, the Heinz School, Carnegie Mellon University. We thank Douglas Laycock for his helpful comments. Jodi Gillis, Nathan Johnson, Ruth Silverman, and Arlene Simon provided valuable research assistance. Loewenstein's research was supported by the Russell Sage Foundation. Issacharoff's research was assisted by funding from the members of the Dean's Roundtable at the University of Texas School of Law and by the Shell Oil Foundation. Camerer's research was supported by the National Science Foundation, Grant SES 90-23531.

[Journal of Legal Studies, vol. XXII (January 1993)]

(c) 1993 by The University of Chicago. All rights reserved. 0047-2530/93/2201-0005\$01.50 
According to this model, ${ }^{1}$ so long as the parties share a common assessment of the potential risks and rewards from continuing litigation, ${ }^{2}$ they will assign a jointly held expected value to the litigation. At that point, any settlement above the expected value minus anticipated costs is desirable for a plaintiff, and any settlement below the expected value plus anticipated costs is desirable for a defendant. Therefore, risk-neutral or risk-averse parties with similar expectations regarding the award amount contingent on nonsettlement have an incentive to settle that increases with the magnitude of the settlement zone. ${ }^{3}$

The most commonly cited and frequently tested explanation for nonsettlement is the Priest-Klein selection hypothesis. ${ }^{4}$ This model posits that parties possess imperfect information, which causes them to estimate a case's value with error. ${ }^{5}$ Cases that fail to settle are those in which the

${ }^{1}$ For the model's primary development, see Richard A. Posner, An Economic Approach to Legal Procedure and Judicial Administration, 2 J. Legal Stud. 399 (1973); and William M. Landes, An Economic Analysis of the Courts, 14 J. Law \& Econ. 61 (1971). Applications of this basic economic model to legal procedures include Geoffrey P. Miller, An Economic Analysis of Rule 68, $15 \mathrm{~J}$. Legal Stud. 93 (1986) (applied to Rule 68 offers of judgment); Samuel Issacharoff \& George Loewenstein, Second Thoughts about Summary Judgment, 100 Yale L. J. 73 (1990) (applied to Rule 56 summary judgment).

2 John P. Gould, The Economics of Legal Conflicts, 2 J. Legal Stud. 279, 296 (1973) (“"a critical component in the motivation of . . . individuals to settle out of court is agreement on the probabilities of the court's action"').

${ }^{3}$ The contract zone (or "settlement zone") is the nonempty set of agreements that both parties prefer to a dispute-resolution procedure. See Robert D. Cooter \& Daniel L. Rubinfeld, Economic Analysis of Legal Disputes and Their Resolution, 27 J. Econ. Lit. 1067, 1075-78 (1989); Issacharoff \& Loewenstein, supra note 1, at 98.

${ }^{4}$ See George L. Priest \& Benjamin Klein, The Selection of Disputes for Litigation, 13 J. Legal Stud. 1 (1984); George L. Priest, Reexamining the Selection Hypothesis, 14 J. Legal Stud. 215 (1985). We leave out of our consideration the additional effect of strategic bargaining. It may be in the interest of bargainers to commit to established bargaining positions in order to negotiate more favorable agreements. See Thomas C. Schelling, An Essay on Bargaining, 46 Am. Econ. Rev. 281, 287-88 (1956). Bargainers who are able to commit credibly shift the zone of agreement in their favor. See Vincent P. Crawford, A Theory of Disagreement in Bargaining, 50 Econometrica 607, 609-10 (1982). This is particularly the case with institutional defendants who are repeat players in litigation and who may be able to dissuade potential plaintiffs from filing suit with the prospect of high investment levels. In situations involving repeat players, "the stakes will almost surely differ between the parties, because the alternative costs of their future activities are unlikely to be equal." Priest \& Klein, supra, at 28. Commitments are credible, however, only if bargainers face large costs to backing down. This scenario occurs, for example, in labor-management negotiations in which union negotiators stake their reputations on achieving a certain wage increase. This strategy can be optimal even when it risks a positive probability of impasse. Impasse is inevitable if the bargainers commit to irreversable and incompatible bargaining positions. See Schelling, supra, at 287.

${ }^{5}$ The economics literature also attributes impasses to uncertainty about the bargaining opponent's reservation value. See Linda C. Babcock, Impasses in Contract Negotiations: Why Do Bargainers Use Arbitration? (unpublished manuscript, Carnegie-Mellon Univ., 1991) (on file with authors). A ready example arises in labor-management negotiations, 
plaintiff overestimates and/or the defendant underestimates the expected value of going to trial. Adhering to conventional assumptions in economic modeling, the selection hypothesis assumes that estimation errors are random, that is, they equal zero on average. Cases that go to trial are simply the unlucky ones in which the plaintiff's and defendant's errors compound to eliminate the settlement zone that would otherwise arise from the risks and costs associated with trial. ${ }^{6}$

The Priest-Klein model has been tested with field data ${ }^{7}$ and experimen-

where there is uncertainty about the firm's profitability, the consequences of a strike to both parties, arbitrator preferences, and the opponent's beliefs about arbitrator preferences. See Beth Hayes, Unions and Strikes with Asymmetric Information, 2 J. Lab. Econ. 57 (1984); Joseph S. Tracy, An Empirical Test of an Asymmetric Information Model of Strikes, 5 J. Lab. Econ. 149 (1987); and Linda C. Babcock \& Craig A. Olson, The Causes of Impasses in Labor Disputes, 31 Ind. Rel. 348 (1992).

${ }^{6}$ A second source of information asymmetry may be attributed to principal-agent relationships. See Brian P. McCall, Interest Arbitration and the Incentive to Bargain, J. Conflict Resolution 151 (1990). Negotiators (agents) may prefer to use costly dispute-resolution procedures in environments that are unfavorable to their constituents (principals). Negotiators will avoid settlement if the principal cannot distinguish between agent shirking and an unfavorable bargaining environment. This type of relationship may exist within labor unions in contract negotiations or between a lawyer and a client in pretrial bargaining. See, generally, Geoffrey P. Miller, Some Agency Problems in Settlement, 16 J. Legal Stud. 189 (1987) (discussing incomplete picture of legal bargaining when competing claims of attorneys and clients for resources are not considered).

Problems of agency are particularly acute in contingent-fee cases. See Daniel J. B. Mitchell \& Murray L. Schwartz, Theoretical Implications of Contingent Legal Fees, 12 Q. Rev. Econ. \& Bus. 69 (1972); Kevin M. Clermont \& John D. Currivan, Improving on the Contingent Fee, 63 Cornell L. Rev. 529 (1978). They are also acute where the recovery of the plaintiff can be played off against payment of plaintiff's counsel. For example, in Evans v. Jeff D., 475 U.S. 717 (1986), the Supreme Court approved a settlement offer made contingent on the waiver of attorneys' fees by the plaintiffs' counsel. The facts of the case made the agency issue more dramatic since plaintiffs' counsel was representing a class of institutionalized mentally retarded minors-a group with whom he was unable to contract around the problems of attorney nonrecovery in a fee-waiver settlement. But the tension between principal and agent may lead to nonoptimal decisions by plaintiff under a variety of circumstances, as Professor Miller has shown. Miller, supra, at 209.

${ }^{7}$ Empirical assessments of the Priest-Klein selection hypothesis principally have evaluated the likelihood of a plaintiff's judgment in a litigated case. According to Priest and Klein, where the stakes in litigation are roughly comparable and where both parties have equal abilities to predict the outcome, plaintiffs should prevail at trial roughly 50 percent of the time. See Priest \& Klein, supra note 4, at 5, 17-22 and n.42 (setting forth the argument and mathematical proof for this hypothesis); Priest, supra note 4, at 219. Empirical tests of the Priest-Klein hypothesis have primarily involved plaintiff success rates in cases that proceed to trial. See, for example, Priest \& Klein, supra note 4, at 31 n.60 (analyzing success rates in tried cases in Cook County, Illinois); J. Mark Ramseyer \& Minoru Nakazato, The Rational Litigant: Settlement Amounts and Verdict Rates in Japan, 18 J. Legal Stud. 263 (1989) (examining plaintiff success rates in Japan); Theodore Eisenberg, Litigation Models and Trial Outcomes in Civil Rights and Prisoner Cases, 77 Geo. L. J. 1567 (1989). A recent major study of cases going to judgment in California found that the Priest-Klein hypothesis had limited predictive force compared with variables such as party wealth, contingent or noncontingent payment of plaintiff's counsel, repeat litigant status of the parties, and the 
tally. A recent study by Linda Stanley and Donald Coursey ${ }^{8}$ is most relevant to this article. Subjects bargained over the division of 100 valuable tokens. If they were unable to determine a division during the allotted negotiation period, all the tokens were given to one subject or the other depending on whether an urn containing 100 red and white chips contained more red or more white chips. Nonsettlement costs were imposed on both parties. Before negotiating, each subject privately sampled a certain number of chips from the urn with replacement. Stanley and Coursey manipulated two variables: the number of chips each subject sampled and the magnitude of nonsettlement costs. The Priest-Klein model predicts that settlement rates will increase with the number of chips drawn from the urn since the variance of subjects' predictions is larger with a smaller drawing of chips. ${ }^{9}$ This prediction was supported. The second prediction, however-that settlement rates would increase with legal costs-was not borne out. Stanley and Coursey discussed a variety of possible explanations for this result, including the possibility that increasing the settlement zone, although increasing the scope for settlement, also increases the zone of indeterminacy and the scope for bargaining. They also speculated that, although "the experiment above was not designed to study the psychological effects of the negotiation process, . . . these effects may determine, in part, the outcome of negotiations." 10

While we also test the Priest-Klein model in an experimental setting, our specific focus is on psychological factors that challenge its central assumptions. First, there exists substantial psychological research documenting the prevalence of "egocentric" biases in estimation. When people estimate quantities that are relevant to their own self-image-for example, the fraction of credit that they deserve for a collaborative task, how well they drive (compared to others), the esteem in which others hold them, or how well they have performed a task-their estimates tend to be biased in a self-serving fashion. This raises the question of whether parties to a lawsuit in fact can make an unbiased estimate of the value of a case. As Janet Malcom's introductory quotation suggests, plaintiffs

availability of insurance to cover any potential judgment. Samuel R. Gross \& Kent D. Syverud, Getting to No: A Study of Settlement Negotiations and the Selection of Cases for Trial, 90 Mich. L. Rev. 319 (1991).

${ }^{8}$ Linda R. Stanley \& Donald L. Coursey, Empirical Evidence on the Selection Hypothesis and the Decision to Litigate or Settle, 19 J. Legal Stud. 145 (1990).

${ }^{9}$ One might expect subjects to lower their reservation values to take account of the high variance when only a small number of chips are drawn. Stanley \& Coursey, however, did not discuss this complication (id.).

${ }^{10} I d$. 
are likely to systematically overestimate the value of their claims, and defendants are likely to underestimate the value of claims brought against them.

Second, the Priest-Klein hypothesis and other legal-economic explanations for nonsettlement assume that the motives for settlement are purely pecuniary. Both plaintiff and defendant are assumed to maximize the expected value of their claims or the expected utility of the monetary outcome. In contrast, a rich literature in psychology and, more recently, a plethora of experiments conducted by economists testing various gametheory propositions indicate that people are influenced powerfully by considerations of fairness. Although the importance of fairness relative to pecuniary concerns may depend on the magnitude of the stakes and other features of the case, existing research suggests that judgments of fairness will exert a significant influence on pretrial negotiations.

We present results from an experiment designed to test the Priest-Klein model of settlement from the vantage point of the two considerations raised above. In an experimental simulation of pretrial negotiations in a dispute arising from a motor-vehicle accident, we monitored the perceptions of parties regarding the judgment they anticipate if they were to go to trial. We then examined the relationship between these perceptions and bargaining behavior and settlement. We presented subject pairs with identical case materials, designated one defendant and the other plaintiff, endowed the defendant with a fixed fund from which any settlement or judgment would have to be paid, and allowed the parties to attempt to negotiate a settlement. Absent a settlement, funds were distributed according to a preexisting independent "trial" judgment, and litigation costs (that were manipulated in the experiment) were levied.

Our findings demonstrate the importance of both psychological considerations discussed above. Contrary to the explicit assumption in the Priest-Klein model, predictions of the value of the claim and judgments of what settlement would be fair are both biased in a self-serving manner. Moreover, the magnitude of the bias is a strong predictor of nonsettlement. Challenging the assumption that parties are guided purely by pecuniary concerns, we find that the magnitude and distribution of costs for going to trial do not have the predicted effects on the probability of settling or the value of settlements. Despite the moderate pecuniary incentives (that induced the subjects' participation in the first place), subject disputants seemed more concerned with achieving what they considered to be a fair settlement of the case than maximizing their own expected value.

Given the burgeoning caseloads in the court system, impediments to settlement have received increasing attention. Legal costs impose bur- 
dens on both parties to a suit and on society. One study of asbestos suits found that only thirty-seven cents of every dollar spent by both sides ends up in the plaintiff's hands. ${ }^{11}$ Thus, the causes of impasse-the major focus of our study - are not only of theoretical interest but also of great practical importance. Our intention is to demonstrate that consideration of the psychological factors influencing disputants' behavior can enhance the explanatory power of the economic analysis of settlement.

\section{Psychological Factors in Bargaining}

\section{A. Self-serving Biases}

Whereas the common assumption in economics is that errors of judgment will not be systematically biased, such biases have been the active focus of recent research in psychology. ${ }^{12}$ Studies have documented biases in probability judgments that are not eliminated by incentives for accuracy or feedback. ${ }^{13}$ Such biases include overweighting of vivid information, revision of probability estimates more radically in some situations and less radically in others than is called for by Bayes's theorem, failure to expect regression to the mean (and misattribution when it occurs), misapplication of the law of large numbers to small samples, and a tendency to think that the plausible conjunction of two events is more probable than is either event alone. These biases are widely believed to result from the use of judgmental heuristics - cognitive rules of thumb that are naturally adapted to limited human information-processing capabilitiesinstead of optimal statistical rules.

Most relevant to the current endeavor are "egocentric" or "self-serving" estimation biases. Seminar participants overestimate the amount of time they speak relative to estimates by other participants. In two-person discussions, both people typically believe they spoke more than half the time. When asked to guess the fraction of various household tasks they are responsible for, married couples give estimates that add up to more than 100 percent. ${ }^{14}$

11 James S. Kakalik et al., Costs of Asbestos Litigation 38-40 (1983).

${ }_{12}$ An excellent introduction to this line of research is Judgment under Uncertainty: Heuristics and Biases (Daniel Kahneman, Paul Slovic, \& Amos Tversky eds. 1982) (hereinafter Judgment under Uncertainty).

${ }^{13}$ See Colin F. Camerer, Do Biases in Probability Judgment Matter in Markets? Experimental Evidence, 77 Am. Econ. Rev. 981 (1987); Colin F. Camerer, George Loewenstein, \& Martin Weber, The Curse of Knowledge in Economic Settings: An Experimental Analysis, 97 J. Pol. Econ. 1232 (1989).

${ }^{14}$ See Michael Ross \& Fiore Sicoly, Egocentric Biases in Availability and Attribution, in Judgment under Uncertainty, supra note 12, at 179. 
There is much disagreement in psychology about the origin of selfserving biases. Some argue that the biases are caused by the motivation to feel better about oneself. ${ }^{15}$ Others argue that self-serving biases are simply an artifact of cognitive processes and serve no motivational or adaptive purpose. ${ }^{16}$ Thus, while the existence of egocentric biases is rarely disputed by psychologists, their cause is an active topic of debate.

Egocentric biases have also been observed in dispute settings. A classic study measured student perceptions of a contentious football game between Princeton and Dartmouth. ${ }^{17}$ Students from both schools watched a film of the game and rated the number of penalties committed by both teams. On the one hand, Princeton students saw the Dartmouth team commit twice as many flagrant penalties and three times as many mild penalties as their own team. On the other hand, Dartmouth students recorded an approximately equal number of penalties by both teams. Team allegiance influenced the students' perceptions of penalties.

Two social psychologists demonstrated self-serving interpretations of fairness in a work context. ${ }^{18}$ Subjects were asked to specify the fair rate for two people who had worked either ten or seven hours at a task. The person who worked seven hours was always paid \$25; subjects were asked how much the person who worked ten hours should be paid. When they had worked seven hours, they thought the other person should be paid $\$ 30.29$ for ten hours of work. But when they had worked ten hours, they thought they deserved $\$ 35.24$. The researchers cited the difference between $\$ 30.29$ and $\$ 35.24$ (\$4.95) as evidence of a self-serving bias in wage demands.

${ }^{15}$ See Shelley E. Taylor \& Jonathon D. Brown, Illusion and Well-being: A Social Psychological Perspective on Mental Health, 103 Psychological Bull. 193 (1988). The fact that most people tend to exaggerate their abilities and the esteem in which others hold them while depressives are more realistic in their self-appraisals lends credence to the view that some degree of optimism is functional. See Lauren B. Alloy \& Lyn Y. Abramson, Judgment of Contingency in Depressed and Non-depressed Students: Sadder but Wiser? 108 J. Exp. Psychology: Gen. 441 (1979); Lionel Tiger, Optimism: The Biology of Hope (1980).

${ }^{16}$ Advocates of the cognitive perspective point to evidence such as the finding that married couples' estimates of their responsibility for undesirable outcomes (for example, "causing arguments that occur between the two of you") also add up to more than 100 percent. See Ross \& Sicoly, supra note 14, at 184.

${ }^{17}$ Albert H. Hastorf \& Hadley Cantril, They Saw a Game: A Case Study, 49 J. Abnormal \& Soc. Psychology 129 (1954).

${ }^{18}$ David M. Messick \& Keith P. Sentis, Fairness and Preference, 15 J. Exp. Soc. Psychology 418 (1979). A doctoral student of Messick's obtained very similar results in a study involving real payoffs. See David M. Messick \& Keith P. Sentis, Fairness, Preference, and Fairness Biases, in Equity Theory: Psychological and Sociological Perspectives (David M. Messick \& Karen S. Cook eds. 1979) (reporting the results of E. Van Avermaet, Equity: A Theoretical and Experimental Analysis (unpublished Ph.D. dissertation, Univ. California, Santa Barbara 1974)). 


\section{B. Fairness}

In experimental studies, concern for fairness and unfairness affects bargaining. ${ }^{19}$ The classic example is ultimatum bargaining: one person divides an amount between herself and another person. If the other person rejects the proposed division, both people get nothing. Self-interested bargainers who are neither altruistic nor envious should offer the smallest possible amount (usually a penny) and the offer should be accepted. But, in most studies, people keep an average of 60 percent of the amount for themselves and offer 40 percent to the other person. When less than 20 percent is offered, the offer typically is rejected. ${ }^{20}$

Of course, even if a person is not fair-minded, she might offer 40 percent to the other person simply because she fears the other person will reject a lower offer. True concern for fairness can be separated from this kind of enlightened self-interest (that masquerades as concern for fairness) by modifying the game so that the second person must accept the first person's offer. ${ }^{21}$ In such dictator games, roughly equal numbers of subjects offer zero and offer an equal split of the total amount. ${ }^{22}$ Taken together, the evidence from ultimatum and dictator games shows that some people simply prefer to make fair offers and others make fair offers only because their bargaining partners will reject unfair ones.

Surprisingly high offers in the ultimatum game led experimenters to study more complicated, multistage bargaining in which the amount being divided is reduced at each stage (reflecting the costs of delay in reaching an agreement) and the final stage is an ultimatum game. In most studies, offers were somewhere between an equal split of the amount being divided and the offer predicted by a game-theoretic analysis assuming selfinterest (and foresight about the outcome of bargaining in future rounds). ${ }^{23}$ The most curious observation is that 80 percent of the offers

${ }^{19}$ See, for example, Reinhard Selten, Equity and Coalition Bargaining in Experimental Games, in Laboratory Experimentation in Economics: Six Points of View (Alvin E. Roth ed. 1987).

${ }^{20}$ See Richard H. Thaler, Anomalies: The Winner's Curse, 2 J. Econ. Persp. 195 (1988); Werner Güth \& Reinhard Tietz, Ultimatum Bargaining Behavior: A Survey and Comparison of Experimental Results, 11 J. Econ. Psychology 417 (1990).

${ }^{21}$ This modification was first suggested by Daniel Kahneman, Jack L. Knetsch, \& Richard H. Thaler, Fairness and the Assumptions of Economics, 59 J. Bus. S285 (1986).

${ }^{22}$ See Robert Forsythe, Joel L. Horowitz, N. E. Savin, \& Martin Sefton, Fairness in Simple Bargaining Experiments, Games \& Econ. Behav. (1992, in press).

${ }^{23}$ See Jack Ochs \& Alvin E. Roth, An Experimental Study of Sequential Bargaining, 79 Am. Econ. Rev. 355 (1989); Gary E. Bolton, A Comparative Model of Bargaining: Theory and Evidence, 81 Am. Econ. Rev. 1096 (1991); Eric Johnson, Colin F. Camerer, Sankar Sen, \& Talia Rymon, Behavior and Cognition in Sequential Bargaining (unpublished manuscript, Univ. Chicago 1991) (available on request). 
rejected at one stage of bargaining are followed by counteroffers that offer less money. For example, a typical subject who turns down an offer of $\$ 1.75$ out of $\$ 5$ then will propose an equal split giving himself $\$ 1.25$ out of $\$ 2.50$. These disadvantageous counteroffers are clear evidence that some people sacrifice money for the sake of fairness.

\section{Self-serving Assessments of Fairness in Bargaining}

While large numbers of psychology studies show self-serving assessments and many game-theory experiments show that assessments of fairness play a role in bargaining, only a few studies have combined the two phenomena to show that self-serving assessments of the fairness of different bargaining outcomes can cause disagreements resulting in inefficiencies. In one study, pairs of players bargained over 100 chips that determined their chances of winning a dollar prize (for example, thirty-seven chips gave a 37 percent chance of winning) ${ }^{24}$ One player's prize was $\$ 20$ and the other's $\$ 5$. Notice that there are two ways to split the chips equally: give fifty chips to each (equal chance of winning) or give twenty chips to the $\$ 20$-prize player and eighty chips to the $\$ 5$-prize player (equal expected dollar winnings). When neither player knew the prize amounts, they agreed to divide the chips about equally; only about 10 percent of the pairs disagreed and ended up with nothing. When only the \$5-prize players knew both prize amounts, however, they insisted on getting eighty chips (to equalize dollar winnings). Since the $\$ 20$-prize players wanted fifty chips to equalize their chances of winning, about 30 percent of the pairs disagreed. Thus, the tendency to focus self-servingly on the kind of equal split that favored oneself created disagreement. ${ }^{25}$

In another study, pairs of MBA students negotiated the hypothetical sale of a piece of land, knowing only the value of the land (if they were buying it) or its cost (if they were selling it). ${ }^{26}$ All pairs agreed on a sale price. Trouble began when students negotiated a second time with the same partner after finding out the value or cost of the land to their partner. Students who had struck a good deal in the first negotiation thought that selling the land at the same price was fair; their partners often disagreed, preferring to split the difference between the land's cost and its value or

\footnotetext{
${ }^{24}$ See Alvin E. Roth \& J. Keith Murnighan, The Role of Information in Bargaining: An Experimental Study, 50 Econometrica 1123 (1982).

${ }^{25}$ When both players knew the prize amounts, however, and knew that the other player knew them too, disagreements were slightly fewer (18 percent). This suggests that competing equal-split points contribute something to inefficiency (from 10 to 18 percent) and asymmetry of information contributes a little bit more (from 18 to 30 percent). Id. at 1135 .

${ }^{26}$ Colin F. Camerer \& George Loewenstein, Information, Fairness, and Efficiency in Bargaining, in Justice (Barbara A. Mellers ed. 1993, in press).
} 
use some price they thought was more fair than the first-round price. While none of the pairs disagreed in the first negotiation, 20 percent disagreed in the second negotiation when self-serving assessments of fair prices influenced the bargaining. This observation is reinforced by the finding in a recent labor-negotiation experiment that the difference between two opponents' assessments of a fair wage helped to predict the speed with which they reached agreement. ${ }^{27}$

\section{Summary}

The Priest-Klein model and most other models of bargaining under imperfect information share two common assumptions: people estimate risks without bias, and people are concerned only with their own monetary payoff (with some adjustment for risk preference). In this article, we test both these assumptions. First, we examine whether estimates of potential trial outcomes are unbiased (as assumed by the Priest-Klein model) or biased in a self-serving manner (as predicted by psychological research). Second, we test two competing explanations of bargainer behavior: one assumes that disputants maximize their own expected value (or expected utility of money), while the other assumes disputants are willing to sacrifice expected value for the sake of fairness.

In the bargaining experiment discussed below, we test for the existence of a pervasive self-serving bias by asking subjects to predict the case's value. The experimental setting measures bias in expectations by providing adversarial parties with identical information, assuring them that the other party has no additional information, and introducing financial incentives for reporting expectations accurately. We test whether subjects are maximizing expected value or attempting to achieve fairness in two ways. First, we manipulate costs and check whether the manipulation has the effect predicted by the economic model. For example, shifting the settlement zone by reallocating $\$ 1,000$ in trial costs from defendant to plaintiff should reduce settlement values by an average of $\$ 1,000$. Failure to observe such a shift in settlement values would be evidence against pecuniary maximization and would more tentatively support the proposition that subjects were concerned with fairness. Second, we examine whether settlement values and settlement rates are better explained by subjects' predictions of the amount the judge will award if the case is not settled (as the economic model predicts) or by their assessments of what they believe would be a fair settlement.

${ }^{27}$ Leigh Thompson \& George Loewenstein, Egocentric Interpretations of Fairness and Interpersonal Conflict, 51 Org. Behav. \& Hum. Decision Processes 176 (1992). 
Besides examining the magnitude of self-serving bias and its effect on impasse, we also question why the bias occurs. If both bargainers' beliefs about fairness and arbitrator decisions are biased in a self-serving manner, dispute resolution will be aided by interventions that bring parties' expectations closer. Many techniques of mediation and facilitation, such as active listening and role reversal, can be understood in these terms. ${ }^{28}$ Conversely, if bias interferes with the ability of parties to converge on an efficient settlement, the premises underlying expansive exchanges of information in the discovery process may be called into question. Understanding the causes of the bias can contribute to the design of such interventions as may be necessary to facilitate efficient settlements.

\section{THE EXPERIMENT}

Eighty undergraduates from the University of Chicago and eighty students at the University of Texas at Austin School of Law participated in our study. We assigned pairs of subjects the roles of plaintiff and defendant, and then they attempted to negotiate the settlement of a tort case arising from the collision of an automobile and a motorcycle. The injured plaintiff (the motorcyclist) was suing the driver of the automobile for $\$ 100,000$. We gave both subjects precisely the same case materials and informed them that the information they were given was identical. The subjects received twenty-seven pages of actual testimony abstracted from a real case in Texas, including witness testimony, police reports, maps, and the testimony of the parties. ${ }^{29}$ Subjects were informed that, after editing the case materials, we had given them to a judge in Texas who had reached a decision regarding whether there would be compensation to the plaintiff and, if so, the amount. ${ }^{30}$

Before negotiating, we asked the subjects to write down their guess of what the judge would award. We told them they would receive a $\$ 1$ bonus at the end of the session if their prediction was within $\$ 5,000$ (plus or minus) of the actual judge's award. We also asked what they considered

\footnotetext{
${ }^{28}$ See Roy Lewicki \& Joseph Litterer, Negotiation (1985).

${ }^{29}$ The testimony is available from the authors on request.

${ }^{30}$ We told the subjects that the judge had seen the same case materials for two reasons. First, we wanted the subjects to know that an independent arbiter had read exactly the same materials they were reading. Second, we wanted them to know we had not selected the case based on the judgment awarded by the judge but instead had first selected the case and then solicited a judgment on it. If we had simply chosen the judgment from an actual trial, subjects might have anticipated that we would choose a case with an award amount lying within a particular desired range. A law professor at the University of Texas (our "judge") specializing in civil litigation issues computed the actual trial figure.
} 
a fair amount for the plaintiff to receive in an out-of-court settlement from the vantage point of a neutral third party.

We paid each subject a fixed fee (\$3 at Chicago and $\$ 4$ at Texas) for participating and gave the defendant an extra $\$ 10$. The two parties then attempted to negotiate a settlement orally. If they settled, the defendant paid the plaintiff an amount of money that depended on the value of the settlement. Every $\$ 10,000$ from the case was equivalent to $\$ 1$ for the subjects. For example, given a $\$ 60,000$ settlement, the defendant kept $\$ 4$ and gave $\$ 6$ to the plaintiff. If the parties failed to settle, the defendant had to pay the plaintiff an amount that depended on the judge's decision in the case. Since the actual judgment was $\$ 30,560$, this meant the defendant paid the plaintiff $\$ 3.06$. In addition, costs for not settling were levied and systematically manipulated. Finally, after the negotiation ended, we asked both parties to recall and rate the importance of arguments favoring both the plaintiff and the defendant.

We designed the experiment to test the two hypotheses discussed above. We gave the subjects identical testimony and information about the rules of the game, so that any systematic differences in estimates between defendant and plaintiff could not be attributed to differences in information. Even though there was uncertainty about what the judge would do if the parties could not settle, no private information was held by either party. ${ }^{31}$ In addition, we guaranteed both parties that the information was the complete set of facts discoverable as to the controversy: that the judge ruled on the case based on the same case materials. We also chose a fact-intensive scenario in which witness credibility and coherence of testimony would predominate; there were no unclear legal issues that might prompt uncertainty as to arbitrator conduct. ${ }^{32}$

First, all subjects were paired off and assigned the role of plaintiff or defendant. Subjects were given thirty minutes to read the case and a page explaining the rules for negotiating and the costs they would face if they failed to reach an agreement. (The latter page is presented in the Appendix for one condition.) After reading the case materials, subjects made a prediction of the judge's settlement and stated what they thought was a

${ }^{31}$ We also insured that no problems created by principal-agent relations would affect the outcome. For principal-agent issues to arise, there must be both a negotiator (the agent) and constituents (the principals). In our experiment, the parties were negotiating for themselves - the use of lawyers (or other agents) to negotiate for the parties was not permitted.

${ }^{32}$ Because the participants were one-time players, the risk of strategic bargaining seemed limited. Commitment theory assumes an environment in which the parties are able to make their commitments credible. To be credible, there must be a mechanism whereby a bargainer can make the commitment irreversible (or at least extremely costly to abandon). In this experiment, the environment restricted the opportunity to make such commitments. 
fair settlement for the case. They were told that this information would be withheld from the other party. They were then allowed to negotiate for thirty minutes. If they failed to reach a voluntary settlement within that period, the judge's decision determined the plaintiff's payment to the defendant, and legal costs were levied on the parties.

There were four experimental conditions, each of which imposed different costs on the parties in the event of nonsettlement: $A, \$ 10,000$ each; $B, \$ 20,000$ to the defendant, none to the plaintiff; $C, \$ 20,000$ to the plaintiff, none to the defendant; $D, \$ 5,000$ each. To calculate the actual costs of nonsettlement to the subjects, recall that every $\$ 10,000$ in the case translated to $\$ 1.00$ for the subjects. We imposed these varying conditions for four reasons.

First, virtually all existing theories of bargaining predict that the size of the contract zone and not its distribution between disputants determines the likelihood of settlement. ${ }^{33}$ In contrast, on psychological grounds, one might expect the distribution of costs as well as their sum to influence settlements. ${ }^{34}$ If the parties do focus on costs, then, with asymmetrical costs, ${ }^{35}$ the person favored by lower costs should view this as justifying a more advantageous settlement, while the person with higher costs should view costs as irrelevant. That is, one party will focus on divisions based on bargaining strength (an inverse function of costs), and the other will focus on divisions based on fairness.

A second rationale arises from a comparison of conditions $A$ and $D$. As noted above, there are two possible explanations for any observed effect of self-serving interpretations of fairness on settlements, one operating through expectations of arbitrator behavior, the other arising from bargainers' attempts to achieve what they personally view as a fair settlement. The former explanation suggests that total costs should have a

${ }^{33}$ See, for example, Donald L. Coursey \& Linda R. Stanley, Pretrial Bargaining Behavior within the Shadow of the Law: Theory and Experimental Evidence, 8 Int'l. Rev. L. \& Econ. 161-63 (1988) ("Any mechanism that increases the surplus from settlement [the settlement zone] . . . increases the likelihood of settlement"); Cooter \& Rubinfeld, supra note 3 , at 1076. There are divergent views on this point, focusing on the effect of greater uncertainty in bargaining outcomes in cases with relatively large settlement zones. See Miller, supra note 1, at 113; Vincent P. Crawford, Arbitration and Conflict Resolution in Labor-Management Bargaining, 71 Am. Econ. Rev. 205 (May 1981); Babcock, supra note 5.

${ }^{34}$ See Issacharoff \& Loewenstein, supra note 1, at 102-3.

${ }^{35}$ Examples found in the experimental literature include David M. Messick \& Keith P. Sentis, Estimating Social and Nonsocial Utility Functions from Ordinal Data, 15 Eur. J. Soc. Psychology 389 (1985); Messick \& Sentis, Fairness, Preference, and Fairness Biases, supra note 18 (citing Van Avermaet, supra note 18); Alvin E. Roth \& Michael W. K. Malouf, Game Theoretic Models and the Role of Information in Bargaining, 86 Psychological Rev. 574 (1979). 
major effect on reservation prices and thus on the likelihood of settlement. The second predicts that total costs will not influence settlement rates except insofar as they influence perceptions of fairness. By comparing settlement rates in conditions $A$ and $D$, we can test these two predictions.

The comparison between conditions $A$ and $D$ is also interesting because there has been considerable debate among economists over whether settlement should increase or decrease with the magnitude of the settlement zone. The prevailing view has been that settlement should increase with the magnitude of the settlement zone. ${ }^{36}$ This assumption, however, has been challenged recently on theoretical ground ${ }^{37}$ and tested with mixed results. ${ }^{38}$

Finally, virtually all economic theories of bargaining predict that any shift in the contract zone should result in an equivalent shift in settlement values. Thus, the standard prediction is that settlement values will be equivalent in conditions $A$ and $D, \$ 10,000$ higher in condition $B$, and $\$ 10,000$ lower in condition $C$. The fairness perspective, in contrast, predicts that costs will influence settlement values only insofar as they influence perceptions of fairness. Since we would expect perceptions of fairness to hinge mainly on the case itself and not on the particulars of settlement costs, the counterhypothesis is that settlement values will not be influenced significantly by the distribution of costs.

In the final stage of the experiment, after negotiating, all subjects were asked to list all the arguments they could think of that favored each side and to rate the importance of these arguments on a four-point scale that consisted of "very important," "moderately important," "minor," and "trivial." The page eliciting arguments favorable to the plaintiff instructed the subject, "List all of the arguments you can think of that support a large settlement for [plaintiff] Jones. When you finish listing the arguments, rate each argument in terms of how important you think it is. How much do you think the argument would influence a judge or jury who tried the case?"

One explanation for self-serving biases discussed in the psychological literature is that people naturally tend to pay more attention to their own actions and contributions than to others' ${ }^{39}$ When asked how much

\footnotetext{
${ }^{36}$ See, for example, Henry S. Farber \& Harry C. Katz, Interest Arbitration, Outcomes, and the Incentive to Bargain, 33 Indus. \& Lab. Rel. Rev. 55 (1979).

${ }^{37}$ See Crawford, supra note 4.

${ }^{38}$ See Stanley \& Coursey, supra note 8 (manipulating subjects' nonsettlement costs but failing to find any effect on settlement rates).

${ }^{39}$ See Michael Ross \& Fiore Sicoly, Egocentric Biases in Availability and Attribution, 37 J. Personality \& Soc. Psychology 322 (1979).
} 
housework they contributed or how much they talked in a seminar, they tend to overestimate these values because their own actions were more "salient" and thus more easily recalled than those of other people. In a legal dispute one would expect such egocentric recall to be, if anything, stronger. It is natural to focus on arguments favoring one's own side in order to present one's case to the other party during pretrial bargaining. If egocentric recall or egocentric weighting of arguments is in fact the mechanism underlying self-serving assessments of fairness and biased predictions of the judge's settlement, then we would expect to observe a correlation between recall of arguments, assessments of fairness, and predictions of the judge's settlement. Furthermore, if egocentric assessments of fairness do play a role in nonsettlement, we would expect the recall and importance measures to be significant predictors of both settlement and settlement amounts.

\section{Results}

There were no significant differences between the two subject populations (Chicago and Texas) on any of the key variables, so we analyzed the two groups together. Table 1 presents a breakdown of the percentage of bargaining pairs who settled during the thirty-minute bargaining period and the average settlements for the four cost conditions. Comparing conditions $A$ and $D$, most economic theories of bargaining would predict that condition $A$ would have higher settlement rates than condition $D$ since the costs of nonsettlement (and hence the incentives for settlement) are higher in condition $A$ than in condition $D .{ }^{40}$ Comparing the first three conditions, psychological theories of bargaining would predict $A$ would have higher settlement rates than $B$ and $C$ because symmetrical costs (as in condition $A$ ) permit both parties to focus on fair outcomes, whereas asymmetrical costs (as in conditions $B$ and $C$ ) may lead to different assessments of fairness by the two parties.

Although settlement rates in the four conditions are not significantly different from each other, the ordinal pattern of settlement rates is contrary to both the psychological prediction and that of conventional bargaining theory. Given the lack of significant differences between the conditions, however, our best conclusion is that costs had little effect on settlement rates.

The results with respect to agreement amounts are mixed. On the one

${ }^{40}$ See Orley Ashenfelter, Janet Currie, Henry S. Farber, \& Matthew Spiegel, An Experimental Comparison of Dispute Rates in Alternative Arbitration Systems (unpublished manuscript, Princeton Univ. 1990) (available on request) (finding experimental evidence that dispute rates are negatively correlated with costs to disagreement). 
TABLE 1

Settlement Rates and Values by Cost Condition

\begin{tabular}{|c|c|c|c|c|c|}
\hline \multirow[b]{2}{*}{ CONDITION } & \multicolumn{2}{|c|}{$\begin{array}{l}\text { Cost Allocation } \\
\text { (in Dollars) }\end{array}$} & \multirow{2}{*}{$\begin{array}{l}\text { Number } \\
\text { OF Pairs }\end{array}$} & \multirow{2}{*}{$\begin{array}{l}\text { Percentage } \\
\text { Settling }\end{array}$} & \multirow{2}{*}{$\begin{array}{l}\text { Mean Settlement } \\
\text { (in Dollars) }\end{array}$} \\
\hline & Defendant & Plaintiff & & & \\
\hline$A$ & 10,000 & 10,000 & 20 & 60 & $\begin{array}{l}29,208 \\
(2,819)\end{array}$ \\
\hline$B$ & 20,000 & 0 & 20 & 80 & $\begin{array}{l}42,219 \\
(3,599)\end{array}$ \\
\hline C & 0 & 20,000 & 20 & 85 & $\begin{array}{l}34,112 \\
(2,618)\end{array}$ \\
\hline$D$ & 5,000 & 5,000 & 20 & 70 & $\begin{array}{l}30,393 \\
(2,561)\end{array}$ \\
\hline All conditions & & & & 74 & $\begin{array}{l}34,517 \\
(1,798)\end{array}$ \\
\hline
\end{tabular}

NotE.-Standard errors are in parentheses.

hand, settlement amounts were approximately $\$ 10,000$ higher in condition $B$ than $A$, in line with economic theory. Also consistent with economic reasoning was the lack of a difference in settlement amounts between conditions $A$ and $D$. Contrary to economic models of bargaining, however, settlement amounts, on average, were $\$ 5,000$ higher in condition $C$ than in condition $A$. Economic theory predicts they should be $\$ 10,000$ lower.

Table 2 presents the differences between the plaintiffs' and defendants' predictions of the judge's award and the differences between their perceived fair-settlement points. Here we see strong evidence for selfserving interpretations of fairness. Plaintiffs' predictions of the judge's award, on average, were $\$ 14,527$ higher than defendants'. Mean plaintiffs' fair-settlement values were $\$ 17,709$ higher than defendants'. Both differences are statistically different from zero at the $p=.0001$ level..$^{41}$

Argument recall and importance ratings reveal a similar pattern. Plaintiffs, on average, recalled .49 more arguments favoring themselves than favoring the defendant, while defendants recalled an average of .91 more arguments favoring themselves than favoring the plaintiff. Some imbalance is expected since the arguments in the case were not matched in

${ }^{41}$ Fairness assessments and predictions of the judge's settlement were positively correlated across subjects in the same role ( $r=.73$ for plaintiffs; $r=.71$ for defendants). These high correlations are consistent with the notion that parties use their biased assessment of fairness to predict what a judge would award. As expected given the design of the experiment, there was no relationship ( $r=.004$ and $r=-.05$ ) between plaintiff and defendant predictions of the judge's award or between plaintiff and defendant assessments of fairness. 
TABLE 2

Alternative Measures of the Self-Serving Bias

\begin{tabular}{|c|c|c|c|}
\hline & Plaintiff & Defendant & Difference \\
\hline Fair settlement (in dollars) & $\begin{array}{c}37,028 \\
(2,149)\end{array}$ & $\begin{array}{l}19,318 \\
(1,424)\end{array}$ & $\begin{array}{c}17,709 \\
(2,632)\end{array}$ \\
\hline Prediction of judge (in dollars) & $\begin{array}{l}38,953 \\
(2,128)\end{array}$ & $\begin{array}{l}24,426 \\
(1,746)\end{array}$ & $\begin{array}{l}14,527 \\
(2,747)\end{array}$ \\
\hline $\begin{array}{l}\text { Number of arguments favoring plaintiff }- \text { argu- } \\
\text { ments favoring defendant }\end{array}$ & $\begin{array}{l}.49 \\
(.21)\end{array}$ & $\begin{array}{c}-.91 \\
(.29)\end{array}$ & $\begin{array}{l}1.40 \\
(.36)\end{array}$ \\
\hline $\begin{array}{l}\text { Importance-weighted arguments favoring plain- } \\
\text { tiff - arguments favoring defendant }\end{array}$ & $\begin{array}{l}1.04 \\
(.66)\end{array}$ & $\begin{array}{r}-2.79 \\
(.86)\end{array}$ & $\begin{array}{c}3.77 \\
(1.18)\end{array}$ \\
\hline
\end{tabular}

NotE.-Standard errors are in parentheses.

number or importance. If there were no bias, however, then the imbalance would be in the same direction for both parties. Weighting each argument by the subject's rating of its importance, we see further evidence of a recall bias. Plaintiffs recalled 1.04 more importance-weighted arguments favoring themselves than favoring defendants; defendants recalled 2.79 more arguments favoring themselves.

To determine whether there was a relationship between the magnitude of the self-serving bias and the settlement rates, in Table 3 we examine the differences in the parties' assessments. The differences are broken down by the pairs who settled and those who did not. The evidence for such a relationship is strong. Parties who settled out of court arrived at more similar assessments about what a fair settlement was and what a judge would award than those who failed to settle. For the fifty-nine pairs who settled, the mean difference between the plaintiffs' and defendants' predictions of the judge's settlement, DIFJUDGE, was $\$ 9,050$; for the twenty-one pairs who did not settle, the average difference was $\$ 29,917$. The difference between DIFJUDGE for the two groups is significantly different from zero $(t(78)=3.6, p<.001)$. A similarly significant pattern is evident in the difference between the plaintiffs' and defendants' assessments of a fair settlement, DIFFAIR.

The variable DIFARG represents the number of arguments recalled by the defendant favoring the defendant minus the number favoring the plaintiff plus the number of arguments recalled by the plaintiff favoring the defendant minus the number favoring the plaintiff. This variable represents the tendency of both parties to recall arguments favoring themselves. The analogous variable, DIFIMP, is based on importanceweighted arguments rather than on raw number of arguments. The differ- 
TABLE 3

Magnitude of Self-serving Bias for Pairs Who Did and Did Not Settle

\begin{tabular}{lcc}
\hline \hline & Settled* $^{*}$ & Did Not Settle $\dagger$ \\
\hline DIFFAIR (in dollars) & 11,941 & 33,915 \\
& $(2,792)$ & $(4,782) \ddagger$ \\
DIFJUDGE (in dollars) & 9,050 & 29,917 \\
& $(2,885)$ & $(5,448) \S$ \\
DIFARG & 1.0 & 2.5 \\
& $(.39)$ & $(.76)^{\|}$ \\
DIFIMP & 1.9 & 8.9 \\
& $(1.24)$ & $(2.57)^{\#}$ \\
\hline
\end{tabular}

Note. - Standard errors are in parentheses.

$* N=59$.

$\dagger N=21$.

$\ddagger t(78)=4.0, p<.0001$.

$\S t(78)=3.6, p<.0006$.

$t(76)=1.9, p<.07$.

\#t(76) $=2.7, p<.01$.

ence in DIFARG for those who did and did not settle is marginally significant $(t(76)=1.9, p<.07)$, and the difference for DIFIMP is significant $(t(76)=2.7, p<.01)$.

We ran probit analyses for the probability of settling that reinforce the basic conclusions presented above. The probability of settling decreases with the difference between the parties' assessments of what is fair and what a judge will award. The probability of settlement also decreases with the degree of egocentric recall and the importance rating of arguments, but only the latter effect is significant. Once fairness, assessment of the judge's award, and argument recall and rating are controlled for, the four cost conditions do not affect the probability of settlement. Also noteworthy is the fact that the difference between the two sides' fairness assessments is a slightly better predictor, in terms of both coefficient magnitude and significance, than the difference in predictions of the judge's award.

We also ran regressions to determine the factors that affect the voluntary-settlement amounts. Whereas costs had no effect on the probability of settlement, they did affect the settlement amount. Pairs in condition $B$, where the defendant faced higher costs, settled for a higher amount, on average, than those in the other conditions. No other cost condition differed significantly from the baseline of condition $A$.

Defendants' assessments of fairness and predictions of the judge's award had a major effect on settlement values. For every dollar increase in the defendant's perceived fair-settlement value, actual settlements 
rose, on average, by 50 cents. A dollar increase in the defendant's estimate of the judge's settlement netted an extra 35 cents in the mean settlement. ${ }^{42}$ Again, fairness assessments seem to be marginally better predictors of bargaining outcomes than predictions of the judge's award. Curiously, however, plaintiffs' predictions and fairness values did not have a significant effect on settlement values.

Finally, we examined the degree to which the parties' fairness assessments and award predictions could be explained by the legal costs they faced or their recall of arguments. Generally, costs had no effect with the exception that the defendant's fairness assessments and predictions of the judge's settlement were significantly higher in condition $C$ (where, if anything, they should have been lower). The plaintiffs' fair-settlement points and predictions of the judge's award were marginally and positively related to importance-weighted recall of arguments favoring the defendant and negatively related to importance-weighted recall of arguments favoring the plaintiff. The defendants', however, were unrelated to recall.

\section{Assessing the Role of Self-Serving Bias in Settlement Negotiations}

Our experiment provides strong evidence for the existence of a selfserving bias. The magnitude of the bias is large-approximately one-half the value of the judge's actual settlement-whether measured by predictions of the judge's award or perceived fair-settlement points. Thus, the central assumption of the Priest-Klein model-that errors in the estimation of potential award amounts are random-is rejected.

Moreover, the statistical link between the bias and nonsettlement is strong. The magnitude of the bias, although also present among pairs who settled, is over three times greater for pairs who did not. The strong correlation between the magnitude of the bias in a particular bargaining pair and nonsettlement supports the self-serving bias explanation for nonsettlement. We cannot, however, rule out alternative explanations for the findings. Perhaps, some third factor, such as a particular character trait on the part of the negotiators, influenced both interpretations of fairness and negotiating behavior, creating a statistical association in the absence of a causal relationship. ${ }^{43}$

${ }^{42}$ Of course, these benefits of a sense of entitlement have to be weighed against the increased risk of not settling.

${ }^{43}$ In a subsequent experiment, we eliminated this possibility by manipulating self-serving interpretations of fairness and examining the effect of the manipulation on negotiator behavior and outcomes. We assigned some subjects their roles (plaintiff and defendant) before 
Assuming that the bias does influence settlement, exactly how it does so is unclear. In the introduction, we posited two different views of bargaining behavior-one assuming that bargainers are biased expectedvalue maximizers, the other assuming that they are simply trying to obtain what they believe is a fair deal. The finding that fairness assessments were slightly better predictors of both the probability and amount of settlement than predictions of the judge's award supports the notion that people are trying to reach a fair settlement rather than maximize expected value. Also supportive is the generally weak or absent effect of costs on settlement, settlement amounts, or parties' perceptions of fairness. In the introduction, we hypothesized that perceptions of a fair settlement were likely to depend on the features of the case rather than the costs each side would bear contingent on nonsettlement. The finding that assessed fair-settlement points were not related to costs supports this hypothesis.

One finding that was consistent with the economic perspective was the higher settlements in condition $B$ (elevated defendant costs). Whether this was a fluke or a robust effect is unclear. Contrary to the economic prediction, when plaintiff costs were elevated, the award amount also tended to rise, although the effect was not significant. Also contrary to the received legal-economic wisdom, ${ }^{44}$ the magnitude of the costs did not appear to influence the settlement rate. This finding replicates earlier experimental findings relating to suit settlement.$^{45}$ In sum, the data are not entirely consistent with either of these views, perhaps indicating that neither view is accurate or that there is heterogeneity in the subject population with respect to underlying motivation.

Finally, we tested the recall-based explanation for the egocentric bias by asking subjects to list and rate the importance of arguments favoring both sides. Consistent with this explanation, we observed a significant bias in recall and importance weighting of those arguments. Both defendants and plaintiffs recalled more arguments from the case favoring their own position and believed that a judge or jury would find arguments favoring themselves to be more important than those favoring the other side. We also found that both measures of recall were related to settlement in the expected direction, although the relationship was significant only for the importance-weighted measure. In general, the statistical rela-

reading the case materials and others after reading the case materials but before negotiating. All subjects in the latter group settled out of court; in the former condition, 39 percent failed to settle out of court. See Linda C. Babcock, George Loewenstein, Samuel Issacharoff, \& Colin F. Camerer, Do Bargainers Form Biased Expectations of Fairness in Bargaining? Am. Econ. Rev. (1993, in press).

${ }^{44}$ See Coursey \& Stanley, supra note 33; Cooter \& Rubinfeld, supra note 3.

${ }^{45}$ Coursey \& Stanley, supra note 33. 
tionships between the recall measures and outcome variables (for example, settlement and settlement values) were weaker than those between outcome variables and direct measures of fairness or predictions of the judge's award. This finding is consistent with the notion that such fairness assessments are intervening variables that create a link between recall and bargaining behavior. The weakness of these relationships, however, also could be due to either the fact that recall does not play a role in producing the bias or our relatively crude measures of recall.

\section{Conclusion}

Experimentation is by now commonplace in research on bargaining. ${ }^{46}$ Our experiment, however, differs in two important respects from most others. First, most earlier studies involved stylized disputes in which no contextual information is provided. In experimental research involving arbitration, arbitrated decisions have been reached by drawing a random number from a bingo cage as opposed to using a human arbitrator. In contrast, our dispute placed subjects in a well-understood and familiar negotiating setting, exposed them to an abundance of realistic contextual information, and confronted them with the decision of a real arbitrator.

The reason for using an actual law case was that the self-serving interpretations of fairness that we hypothesize occur in real disputes are more likely to emerge and are more readily studied in an experiment involving a case with multifacted arguments, therefore affording multiple interpretations of fairness. This does not mean that the self-serving bias will not occur in a more stylized dispute. Indeed, there is evidence of such a bias in earlier research on stylized bargaining situations. The richer experimental setting, however, provides a better environment in which to observe the actual magnitude of the bias in real-world disputes.

The design's main disadvantage is that subjects may bring preconceptions of how they should behave in such a situation. We should note, however, that negotiators also bring such preconceptions to actual negotiations. Moreover, the same criticism applies to all experiments. Subtle cues and the subjects' conjectures about the point of the experiment and the situation it is intended to represent will always influence behavior. In our experiment, the influence is simply more explicit.

Our experiment is different from earlier empirical investigations in that it is a one-shot negotiation. Other studies typically observe negotiation

\footnotetext{
${ }^{46}$ See, for example, Alvin E. Roth, Bargaining Experiments, in Handbook of Experimental Economics (John Kagel \& Alvin E. Roth eds. 1992, in press); Robyn M. Dawes \& Richard H. Thaler, Anomalies: Cooperation, 2 J. Econ. Persp. 187 (1988).
} 
outcomes over a series of trials that allow subjects to learn from experience. The benefit of our method is that it permits the use of realistic experimental stimuli and allows for a long bargaining period (30 minutes). Other experiments have involved much shorter bargaining periods.$^{47}$ The disadvantage is that it does not provide information about the effect of learning. On the one hand, if given multiple opportunities to participate in the experiment, subjects might exhibit less bias and greater tendencies to settle. On the other hand, the feedback provided by repeated play could conceivably inflame self-serving assessments and make impasse more frequent if subjects selectively encode feedback or ignore disconfirming feedback instead of learning from it.

In any case, it is unclear whether one-shot experiments or those in which subjects repeatedly confront the same situation more closely approximate conditions prevailing in actual litigation. Most people participate in only a small number of serious disputes, each of which typically differs in important respects from those that come before. Differences between suits experienced in the past and the present controversy complicate the task of drawing insights from the former and applying them to the latter. ${ }^{48}$ Moreover, those parties positioned to benefit from experience-repeat players in litigation-may bring with them strategic considerations that compromise the benefits that might otherwise be garnered from experience. In the context of litigation, it is widely believed that repeat players are more likely to reject efficient settlements in any given dispute because of an overriding interest in the development of the governing positive law or in fostering a reputation for stubbornness that could prove valuable in future disputes.

Another potential shortcoming of our experiment is that subjects negotiated for themselves, whereas, in most high-stakes law suits, litigants hire agents to negotiate on their behalf. As a referee commented, "The fact that litigants may have self-serving biases says nothing about their agents." There are two main reasons why agents might not exhibit the bias.

\footnotetext{
${ }^{47}$ For example, the bargaining time in the Stanley \& Coursey, supra note 8 , experiments was only 4 minutes.

${ }^{48}$ As one commentator noted, "[P]redicting liability in the particular case based on results in past cases is of limited utility. Factual differences between the similar claims and the particular claim make predictions about the particular claim problematic because of the difficulty of isolating those factors on which liability is premised. A witness may not have been credible, a particular exhibit may have been presented in one case but not another, and so on, making comparisons tenuous between the sampled cases and the particular case." Peter Toll Hoffman, Valuation of Cases for Settlement: Theory and Practice, 1991 J. Dispute Resolution 1, 9-10. The difficulty of learning from experience is demonstrated in numerous social-science investigations. See Hillel J. Einhorn, Learning from Experience and Suboptimal Rules in Decision Making, in Judgment under Uncertainty, supra note 12, at 268 (providing evidence of internalization of incorrect rules from experience).
} 
First, agents typically participate in large numbers of cases providing ample opportunitity for learning from experience; after failing to settle a large fraction of cases, they might learn to moderate their demands. This would require agents to learn the right lesson from repeated attempts to settle-namely, that their own demands are unrealistic-as opposed to attributing nonsettlement to the actions of the opposing party ${ }^{49}$ In order to benefit from prior experience, the agents would also need to be able to persuade their less experienced principles to moderate their demands. Whether either of these conditions would be met is questionable.

Second, it is possible that agents face incentives that discourage selfserving assessments of fairness. Incentives might moderate the bias if agents were particularly hurt by nonsettlement, which would be true if repeated nonsettlement caused them to lose business or if fee structures were designed to make nonsettlement unattractive. We suspect, however, that both of these factors work in the opposite direction, encouraging self-serving assessments of fairness. First, trials are much more salient events than settlements; it seems probable that agents are judged more on their ability to win trials than on their ability to settle out of court. Second, since many lawyers bill for services rather than on a contingency basis, there are often strong incentives to avoid settlement so as to increase costs. Finally, the incentives argument is premised on the notion that the bias is a deliberate one. Yet our experiment indicates that the bias is unintentional since it occurred even though we rewarded subjects for accurately predicting the judge's award and did not permit them to share their predictions with the other party (eliminating any strategic value to misestimation). ${ }^{50}$

Self-serving biases create a genuine dilemma for the resolution of legal disputes. The legal literature posits that the failure to settle results from

${ }^{49}$ Evidence obtained in a separate experiment involving the same legal case points to the problematical nature of learning. Before they assessed fairness and predicted the judge's ruling, we informed subjects of the self-serving bias and of its average magnitude. We also had them guess at the other party's estimate of the judge. Being informed of the bias had no effect on the subjects' own predictions or assessments; the magnitude of the bias was unchanged. Knowing about the bias, however, caused them to change their estimates of their opponent's guess of the judge's ruling. Subjects told about the bias thought that the information only applied to the other party; they shifted their estimates of the other party's prediction but did not change their own. See Babcock et al., supra note 43.

${ }^{50}$ The proposition that agents would not exhibit the self-serving bias is testable. A possible joint test for the effect of learning, experience, and the weeding-out effect of the market would involve running experienced lawyers through the experiment to see whether they exhibit the egocentric bias. To test the effect of incentives, one could run the experiment using as negotiators intermediaries whose incentives were tied to those of the principals in a manner approximating the remuneration schemes of agents in actual litigation. Less directly, one could question potential users of legal services about the perceived expertise of different lawyers or law firms and correlate these perceptions with rates of settlement and with successful and unsuccessful litigation. 
uncertainty arising from two sources. First, the state of the law may not be well resolved, resulting in uncertainty about the judge's eventual decision and the opponent's expectation of the judge's decision. In such cases, the legal academic literature's expectation would be that disputes will fail to settle until a sufficient quantum of litigation has clarified the legal rules. ${ }^{51}$ Second, the literature has focused on imperfect or asymmetrical information concerning the facts of the case sub judice as a key obstacle to settlement. ${ }^{52}$

The elaborate discovery rules governing the costly pretrial exchange of information in litigation are predicated on a view that shared information leads to a convergence of perspectives by the parties involved. This view begins with an objective standard from which parties enter the bargaining process: parties have to assess the likelihood of a plaintiff's prevailing at trial, and that assessment will affect the way in which they calculate the expected value of the litigation. Imperfect information allows parties to have nonoverlapping estimations of either the likelihood of a plaintiff's prevailing or the plaintiff's potential award. Since the source of the incompatible estimations of the claim's value is lack of information rather than deep-seated biases or other systemic distortions, it is assumed that the cure lies with additional information. ${ }^{53}$

As structured, civil litigation attempts to promote settlement by isolating genuine uncertainty about the law and by providing the parties with liberal access to each other's information. Unfortunately, both the streamlining of legal issues ${ }^{54}$ and the discovery of information are tremendously costly processes. ${ }^{55}$

This study reveals the shakiness of the assumption that the parties will integrate the information revealed through these processes in an unbiased fashion in order to settle. Rather, our study shows that, even with per-

51 See William M. Landes \& Richard A. Posner, Legal Precedent: A Theoretical and Empirical Analysis, 19 J. Law \& Econ. 249 (1976); William M. Landes \& Richard A. Posner, Adjudication as a Private Good, 8 J. Legal Stud. 235 (1979); Richard A. Posner, Economic Analysis of Law 511 (3d ed. 1986); Charles Silver, Do We Know Enough about Legal Norms, in Social Rules: Origin; Character; Logic; Change (David Braybrooke ed. 1993, in press).

52 See Posner, supra note 51, at 525; Posner, supra note 1, at 422-26. See also Issacharoff \& Loewenstein, supra note 1, at 111-14 (criticizing this view).

${ }^{53}$ Thus, under the Posnerian view of litigation, all rules aimed at producing more common information should encourage settlement by removing any subjective distortions introduced by the parties. Once the additional information is processed and integrated, the biases of the parties will be overcome, their respective assessments of the value of the litigation will converge, and, in the absence of uncertainty about the governing law, settlements should ensue. See Posner, supra note 51, at 525; Posner, supra note 1, at 422-26.

${ }^{54}$ The most common procedures are the motion to dismiss under Rule 12 of the Federal Rules of Civil Procedure and the motion for summary judgment under Rule 56.

${ }^{55}$ See David M. Trubek, Austin Sarat, William L. F. Felstinger, Herbert M. Kritzer, \& Joel B. Grossman, The Costs of Ordinary Litigation, 31 UCLA L. Rev. 72 (1983). 
fectly shared information and a complete absence of disputed legal issues, self-serving biases can cause inefficient impasses. On a theoretical plane, this study points to a view that litigants may not be seeking to maximize their own payoff, as assumed by analyses focusing on settlement zones, but rather may be seeking simply to obtain what they deem fair. If this is the case, we would not expect the settlement zone to make much difference causally, although assessments of fairness no doubt would influence the settlement zone.

If nonsettlement is driven by systematic bias instead of random error or a lack of information, the practical ramifications are numerous. First, it indicates that exchanges of information are not in themselves necessarily conducive to settlement but must be analyzed in terms of how they interact with preexisting biases. Second, it suggests that effective alternative dispute-resolution mechanisms, at least in part, should be directed at "debiasing" parties rather than simply facilitating the exchange of information.

\section{APPENDIX}

\section{INSTRUCTIONS FOR CONDITION A}

\section{Sudden Impact: Elmo Johnson, Defendant}

In this experiment you will play the role of Elmo Johnson. Your goal is to settle a civil suit brought against you by Rick Jones. The case is a distilled version of an actual lawsuit that took place in Texas. Jones accuses you of hitting his motorcycle with your car and causing him injuries. He is asking for $\$ 100,000$ in damages, but if the case goes to trial the actual award could be anything between $\$ 0$ and $\$ 100,000$.

You will have thirty minutes to read the case and thirty minutes to settle the case by negotiating with Jones. We have secured a judgment from a retired Texas judge who was not involved in the original case. If you are unable to settle the case with Jones, you will "go to trial," and the judge's decision will determine the magnitude of the settlement. The judgment is contained in an envelope in our possession.

If you are unable to settle, you will need to add $\$ 10,000$ to whatever the judge determines that you owe Jones. The $\$ 10,000$ is for legal expenses incurred in going to trial. Jones will also bear $\$ 10,000$ in legal expenses so that, if you go to trial, he will need to deduct $\$ 10,000$ in costs from whatever you end up paying him.

We have given you $\$ 12$ to start off with. Please do not discuss this amount with the other subject. But you are responsible for any payments to the other subject as well as legal costs. Every $\$ 10,000$ loss to Johnson is a $\$ 1$ loss for you. So, for example, if you settled at $\$ 50,000$, you would pay the other subject $\$ 5.00$. If you failed to settle, and the judge awarded Jones $\$ 50,000$, then you would pay the other subject $\$ 5.00$, and you would pay the experimenter $\$ 1.00$ in legal expenses. The other subject would get the $\$ 5.00$ you pay but would also pay the experimenter $\$ 1.00$ in legal expenses. 